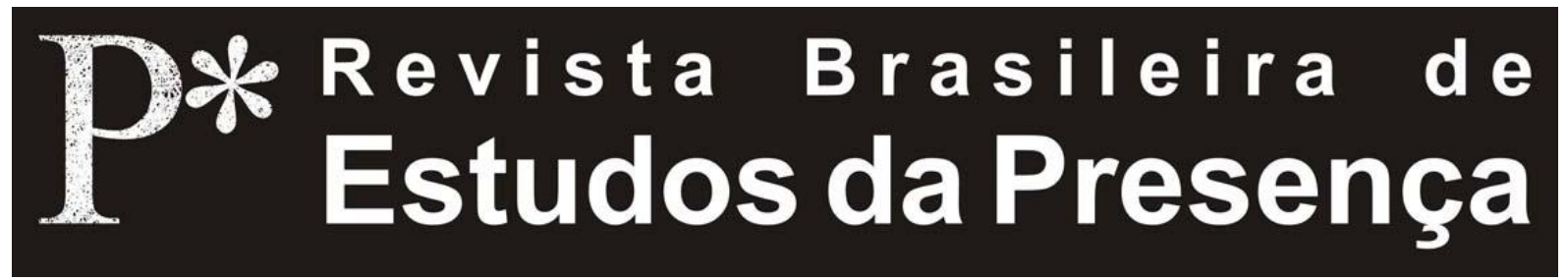

DOI - http://dx.doi.org/10.1590/2237-266020986

ISSN 2237-2660

\title{
11 de Setembro, Arte de Vanguarda?
}

Richard Schechner

New York University - EUA

RESUMO - 11 de Setembro, Arte de Vanguarda? - Pode o ataque de 11 de Setembro ser considerado um evento artístico de vanguarda? $\mathrm{O}$ presente artigo propõe discutir, do ponto de vista da intencionalidade do ato e de sua recepção, o caráter performativo do fato histórico. Para levar a termo o intento, apresenta um panorama histórico da arte de vanguarda, assim como discorre sobre condições históricas e culturais que supostamente operariam como disparadores de tal acontecimento. O texto se debruça, ademais, sobre o caráter espetacular do evento e das condições de sua apreciação numa sociedade balizada sobremaneira pelos aparelhos midiáticos.

Palavras-chave: Arte de Vanguarda. Performance. Terror. Sociedade do Espetáculo.

ABSTRACT - 9/11 as Avant-Garde Art? - Can the attacks of 9/11 be considered an avant-garde artistic event? This article aims to discuss, from the point of view of the intentionality of the act and of its reception, the performative character of that historical fact. To carry forward this intent, it presents a historical overview of avant-garde art, and discusses some of the historical and cultural conditions that supposedly operated as triggers of such an event. The text also focuses on the spectacular character of the event and the conditions for its appreciation in a society greatly limited by the media.

Keywords: Avant-garde Art. Performance. Terror. Society of the Spectacle.

Richard Schechner, 11 de Setembro, Arte de Vanguarda?

R.bras.est.pres., Porto Alegre, v.1, n.2, p. 404-425, jul./dez., 2011.

Disponível em http://www.seer.ufrgs.br/presenca 
RÉSUMÉ - Le 11 Septembre, Art d'Avant-garde? - Les attentats du 11 septembre peuvent-ils être considérés comme un événement artistique d'avant-garde ? Le présent article constitue une réflexion, aussi bien du point de vue de l'intentionnalité de l'acte que de sa réception, sur le caractère performatif de ce fait historique. Dans cette perspective, l'auteur fournit d'abord un panorama historique de l'art d'avant-garde et examine ensuite les conditions historiques et culturelles supposées fonctionner comme les déclencheurs d'un tel événement. Il se penche, par ailleurs, sur le caractère spectaculaire de l'événement et des conditions de son appréciation dans une société excessivement encadrée par des outils médiatiques.

Mots-clés: Art d'Avant-garde. Performance. Terreur. Société du Spectacle.

[Os ataques de 11 de Setembro foram] a maior obra de arte imaginável para todo o cosmos. Mentes alcançando algo em um ato que sequer poderíamos sonhar na música, pessoas ensaiando feito loucas durante 10 anos, preparando-se fanaticamente para um concerto e, então, morrendo, basta imaginar o que aconteceu lá. Você tem pessoas que estão focadas em uma performance e então 5.000 pessoas são mandadas para o além, num só momento. Eu não poderia fazer isso. Em comparação, nós, compositores, não somos nada. Artistas, também, não raro tentam ir para além dos limites do que é possível e concebível, e assim nós despertamos, assim nos abrimos para outro mundo [...]. É um crime porque os envolvidos não deram seu consentimento. Eles não vieram para o concerto. Isso é óbvio. E ninguém os avisou que a vida deles correria riscos. $\mathrm{O}$ que aconteceu, em termos espirituais, foi um salto para fora do seguro, para fora do que é tomado por certo, para fora da vida, que às vezes acontece em pequena escala também na arte, caso contrário, arte não é nada (Stockhausen, 2009). 


\section{Ao desconsiderar Stockhausen, como pode alguém chamar o ataque de 11 de setembro às torres gêmeas uma obra de arte? Qual o valor de tal designação?}

O que pode significar para a arte (da performance), para a autenticidade do que realmente aconteceu e a moralidade social após a primeira década do século XXI, chamar a destruição das Torres Gêmeas uma obra de arte? Para começar a abordar essas questões, preciso remontar à história da vanguarda - porquanto tenham os artistas de vanguarda clamado por mais de um século por uma destruição violenta dos sistemas estético, social e político existentes. De origem francesa, a expressão Avant-garde - cognato de vanguarda e van [à frente] tem sido empregada em inglês desde o final do século XV. O Oxford English Dictionary afirma que a expressão Avant-garde é a linha de frente de um exército, mas também refere-se a estar na frente ou primeiro em qualquer circunstância. No início do século XIX o termo foi tomado por ativistas sociais, utopistas e artistas para significar aqueles que estão à frente do resto da sociedade $^{1}$. A palavra manteve a sua militância, principalmente entre os artistas. A seguir apresento uma série de citações exemplares, organizada, grosso modo, década a década, de um repertório bastante abrangente:

1909, do Manifesto Futurista de F. T. Marinetti: A beleza existe apenas na luta. Não existe obra prima que não tenha um caráter agressivo. A poesia precisa um ataque violento contra as forças do desconhecido, para forçá-las a se render ao homem [...]. Nós queremos demolir museus e bibliotecas [...] porque a arte pode apenas ser violência, crueldade, injustiça.

1918, do Segundo Manifesto Dadaísta: [N]ós estamos preparando o grande espetáculo do desastre, da conflagração e da decomposição. Preparando-nos para pôr um fim ao luto, e para substituir as lágrimas pelas sirenes que se alastram de um continente ao outro.

1938, do manifesto Rumo à Arte Livre Revolucionária de André Breton e Leon Trotsky: [A] arte verdadeira não é

Richard Schechner, 11 de Setembro, Arte de Vanguarda?

R.bras.est.pres., Porto Alegre, v.1, n.2, p. 404-425, jul./dez., 2011.

Disponível em http://www.seer.ufrgs.br/presenca 
capaz de não ser revolucionária, de não aspirar a uma completa e radical reconstrução da sociedade.

1960, do Manifesto Situacionista: O quadro existente não pode dominar a nova forma humana que está aumentando dia a dia com o irresistível desenvolvimento da tecnologia e a insatisfação de seus possíveis usos na nossa vida social carente de sentido [...]. Todo progresso real tem ficado evidentemente suspenso até a solução revolucionária da crise multiforme do presente [...].

Manifestos de artistas defendendo o terror revolucionário praticamente desapareceram após os anos 1960, mesmo em meio às sangrentas manifestações estudantis na França, nos EUA e no México em 1968. Os manifestos do Living Theatre proclamaram a retórica da revolução violenta: "[...] se iremos derrubar a estrutura, teremos de atacá-la de todos os lados, todos os dez mil" (Beck, tópico 16). Mas todos sabiam que o Living Theatre era intrepidamente não violento. Manifestos violentos tornaram-se reais por intermédio das recorrentes explosões efetuadas por grupos como o Weather Underground, não por artistas. Por que os artistas se distanciaram da apologia à violência? Eu não tenho nenhuma resposta definitiva. Possivelmente a tomada de consciência de que o comunismo soviético falhou tirou o gosto pela revolução. Mais provavelmente, dada a Segunda Guerra Mundial, o Holocausto, as bombas atômicas e os medos engendrados pela Guerra Fria, apelando para a violência, não mais pareciam sábios ou éticos.

Isso não impediu professores e artistas de honrar os futuristas, dadaístas, surrealistas e situacionistas. Além disso, as ideias de Antonin Artaud dos anos 1930 saturaram a teoria e a prática teatrais, culminando no extremamente influente teatro da crueldade de 1964. A importância de Artaud para o teatro de vanguarda é canônica, mas ele também poderia estar escrevendo um roteiro para a Al-Qaeda:

1933, do Teatro da Crueldade: O Teatro da Crueldade se propõe a recorrer a um espetáculo de massa; a procurar na

Richard Schechner, 11 de Setembro, Arte de Vanguarda?

R.bras.est.pres., Porto Alegre, v.1, n.2, p. 404-425, jul./dez., 2011.

Disponível em http://www.seer.ufrgs.br/presenca 
agitação de massas enormes, convulsionadas e lançadas umas contra as outras, um pouco daquela poesia das festas e multidões quando, muito raramente hoje em dia, as pessoas invadem as ruas. $\mathrm{O}$ teatro deve nos dar tudo aquilo o que existe no crime, no amor, na guerra ou na loucura, se quiser recuperar a sua necessidade [...] daí o apelo desse à crueldade e ao terror [...] em grande escala (1958c, p. 8586).

Admitindo-se que Artaud estipulava que "[...] a imagem de um crime apresentado nas condições de requisito teatral é algo infinitamente mais terrível para o espírito quando esse mesmo crime é de fato cometido" (1958b, p. 85). Todavia, em nossos dias, as paredes entre o real e o virtual desmoronaram, o teatral e o real se fundiram. $O$ que o 11 de Setembro ofereceu foi um espetáculo da crueldade no sentido artaudiano, "terror [...] em grande escala".

Tomada em conjunto, a mensagem de muitos artistas e teóricos importantes da avant-garde, a qual tem sido insistentemente repetida por mais de um século, é clara: destruir a ordem atual. Criar uma nova ordem ou anarquia. Seriam esses manifestos meras fantasias intelectuais de artistas sem poder? Ou será que eles definem o tom que leva a arte de vanguarda ao entretenimento popular - e além disso para os eventos reais? De fato, a chamada arte elevada e popular se fundiram do mesmo modo com que notícias se confundiram com o entretenimento. Além disso, pelo menos desde 1971, quando Chris Burden teve seu braço alvejado por um amigo, muitos artistas de performance têm ferido a si mesmos, aberto suas veias como arte, têm sido pendurados em ganchos, sacrificado animais e, de diversas maneiras, usado violência real na arte. Os rituais - em relação muito estreita com a arte - incluem flagelação, escoriação, circuncisão, subincisão e assim por diante. A cultura popular está repleta de tatuagens, piercings e cirurgias estéticas que, quaisquer que sejam suas significações psicológicas ou sociológicas, encenam o desejo pela beleza. A estetização e a ritualização da violência, não como representação (tal como nas artes,

Richard Schechner, 11 de Setembro, Arte de Vanguarda?

R.bras.est.pres., Porto Alegre, v.1, n.2, p. 404-425, jul./dez., 2011.

Disponível em http://www.seer.ufrgs.br/presenca 
teatro ou outros meios), mas como atos reais performados no aqui e no agora, são comuns. Todavia, você pode argumentar, excetuando-se os rituais, os manifestos, a arte da performance e as práticas violentas da cultura popular constituem partes deveras abrangentes das práticas da cultura popular da civilização ocidental como um todo, um sistema que Osama Bin Laden e seus aliados explicitamente desprezam, se distanciam e desejam destruir.

Mas isso é realmente assim? Primeiro, o embelezamento por meio da alteração intrusiva do corpo é praticado no mundo inteiro. Segundo, a Al-Qaeda e outros Jihadistas não são adversos ao uso desses aspectos da cultura ocidental que eles consideram úteis. Bin Laden e seus aliados se aproveitam da mídia e da tecnologia avançada, da internet ao sequestro de aviões. A sofisticação tecnológica dos Jihadistas destrói o mito dominante de que eles são primitivos homens das cavernas vivendo em áreas tribais. Na verdade, nenhum lugar está fora da rede global, nem mesmo o nordeste paquistanês e o Afeganistão; e nenhuma tribo ou grupo de pessoas é absolutamente outro. Paradoxalmente, o ocidente e os Jihadistas ocupam esferas deveras separadas do ponto de vista dos valores, ainda que partilhem do mesmo sistema global do ponto de vista técnico. Osama Bin Laden ordena seus seguidores pela internet, libera vídeos de seus discursos e explora instrumentos financeiros globais para pagar operações da Al-Qaeda. Nos meios de comunicação, nos quais qualquer menção é melhor do que a ausência, os jihadistas e os guerreiros contra o terror competem pelo espaço imaginário do palco global.

Quase ao mesmo tempo em que ocorriam, os ataques do 11 de Setembro eram vendidos como entretenimento popular. As representações dos ataques são paradigmáticas da fusão entre notícias e entretenimento, isso não apenas nos Estados Unidos. Em Yueqing, uma cidade rencentemente industrializada a sudoeste de Xangai, vídeos dos ataques estavam à venda no dia 14 de setembro. Em cidades maiores, esses vídeos

Richard Schechner, 11 de Setembro, Arte de Vanguarda?

R.bras.est.pres., Porto Alegre, v.1, n.2, p. 404-425, jul./dez., 2011.

Disponível em http://www.seer.ufrgs.br/presenca 
provavelmente estavam no mercado ainda mais cedo. Como Peter Hessler relatou da China:

Eles foram colocados nas mesmas prateleiras dos filmes de Hollywood. Frequentemente os vídeos do 11 de Setembro se localizavam nas seções mais baratas ao lado de uma infinidade de filmes americanos [...] Todos os vídeos do 11 de Setembro foram embalados para se parecer com filmes de Hollywood. Eu encontrei um DVD intitulado The Century's Greatest Catastrophe; a capa apresentava fotografias de Osama Bin Laden, George W. Bush e as Torres Gêmeas em chamas. Na contracapa, um pequeno ícone indicava que a fita havia sido proibida para menores de 18 anos, pela violência e linguagem (Hessler, 2007, p. 311-312).

Nos Estados Unidos, noticiários são patrocinados. Isto é, as notícias são dadas em pequenas unidades temporais e, após dois ou três itens, há outra unidade temporal, um intervalo comercial. Esse formato de conteúdo de programa e publicidade mostrados sequencialmente é o mesmo para notícias, esportes, séries dramáticas, há vários shows competitivos (Quiz shows, American Idol etc...), incluindo reality shows. O crescimento exponencial dos reality shows e a apresentação de pessoas aparentemente comuns, tanto em meio às suas vidas comuns ou, mais frequentemente, em alguma crise real ou inventada, apaga ainda mais a fronteira entre o real (incluindo as notícias) e o que é produzido como entretenimento (sites de internet como YouTube e outros tantos assemelhados borram ainda mais as fronteiras entre realidade e ficção).

As apresentações televisivas dos ataques de 11 de Setembro logo adquiriram as qualidades de uma série dramática feita para a televisão. Poucas horas depois de os aviões se chocarem contras as Torres Gêmeas, cada rede de televisão encontrou um título melodramático para a sua cobertura dos ataques e dos eventos subsequentes: da $\mathrm{CBC}$, Ataque na América; da ABC, A América sob Ataque; da CNN A Nova Guerra da América. O toque de um tambor dava início ao bombardeio e à invasão do Iraque em 2003. Houve também muito pathos. No dia 14

Richard Schechner, 11 de Setembro, Arte de Vanguarda?

R.bras.est.pres., Porto Alegre, v.1, n.2, p. 404-425, jul./dez., 2011.

Disponível em http://www.seer.ufrgs.br/presenca 
de setembro, a NBC veiculou a notícia A América Chora, tratava-se de histórias comoventes misturadas com chamadas pelo patriotismo exacerbado. No primeiro aniversário do ataque, as redes de televisão veicularam programas como O Dia Que Mudou a América (CBS), Relato do Ponto Zero (ABC), e 11 de Setembro, o dia em que a América Mudou (Fox). Aos ataques do 11 de Setembro se seguiu a guerra dos EUA contra o Iraque, com seus próprios títulos na televisão. Tudo correu sob a rubrica oficial da guerra ao terror.

Os títulos dos programas, o estilo de apresentação das notícias e o sequenciamento dos anúncios publicitários, mostraram como a televisão, mais do que qualquer outra mídia, venderam o 11 de Setembro e a (segunda) guerra do Iraque como uma série feita para a televisão. Essa série incluía muitas subtramas. Havia repórteres incorporados às tropas em terra. Havia atentados-suicidas diários e ataques que o governo e a mídia chamaram de insurgentes. A população era massacrada nesses bombardeios e nos dos militares aliados. Histórias individuais de morte e feridas, dor e pathos, foram ao ar lado a lado com relatos sobre a crescente oposição à guerra, assim como sobre relatos oficiais ritualizados como Nós estamos vencendo. $\mathrm{O}$ ponto mais alto ou talvez o mais baixo dessa competição pela atenção na versão do entretenimento da realidade foi a chegada do presidente Bush, em maio de 2003, em um caça a jato no convés do porta-aviões Abraham Lincoln, no qual uma bandeira gigante proclamava: Missão Cumprida. Aqui o melodrama deu lugar à farsa. Bush usava um macacão de voo, apesar de ele ser o passageiro e não o piloto. Bush ou um imitador de Tom Cruise?

O show de Bush não é o único desse tipo. Essas combinações de notícias, eventos encenados e realidade não fazem do ataque de 11 de Setembro e a Guerra do Iraque arte, mas eles chegam muito perto da forma melodramática das séries de TV. Para teóricos e historiadores da performance, o colapso das categorias estéticas já era familiar a Marcel Duchamp e Andy Warhol. Para eles, o mictório comum chamado de Fonte, 
a famosa estrela de cinema (Marilyn Monroe), o item comum de supermercados (sopa enlatada Campbell's) e a arte elevada não são facilmente distinguíveis, se é que o são. Nos extremos do espectro-mictório, estrela de cinema, e produto de supermercado de um lado e as obras primas penduradas nas majestosas galerias do Metropolitan Museum of Art do outro, as distinções ainda são claras. Mas, hoje em dia, a maior parte do munto das artes e do mundo real vive entre esses dois extremos. $\mathrm{O}$ relato-ficção do 11 de Setembro, incluindo a transmissão e a retransmissão de imagens canônicas das explosões, incêndios, destruição, sequência dos acontecimentos e a guerra, constituem uma absorção dos eventos não apenas na imaginação popular, mas também na apresentação de eventos como objetos de $\operatorname{arte}^{2}$.

Em 11 de setembro havia quatro aviões rumo a seus alvos. Dois atingiram as Torres Gêmeas do World Trade Center, um danificou o Pentágono e o quarto avião, provavelmente indo para a Casa Branca ou para o Capitólio, teve a sua missão frustrada pela resistência dos passageiros e caiu na floresta da Pensilvânia. Dados os quatro aviões e três alvos, por que quase imediatamente o 11 de Setembro veio a significar a destruição das torres do World Trade Center? Nova York é um lugar real, mas ela também é a Gotham de Batman e a Metrópolis do Super-homem. É, também, para muitos americanos, simplesmente a Cidade, quintessencialmente americana e estrangeira ao mesmo tempo. Estranhamente, eu me pergunto se os Jihadistas conheciam New York, New York de Frank Sinatra:

Start spreading the news, I'm leaving today

I want to be a part of it - New York, New York [...]

If I can make it there, I'll make it anywhere ${ }^{3}$

E por que o primeiro ataque ocorreu às $8 \mathrm{~h} 45 \mathrm{~m}$ da manhã e o segundo às $9 \mathrm{~h} 03 \mathrm{~m}$ ? Se os aviões houvessem se chocado com as torres três horas mais tarde, muito mais pessoas teriam morrido. Se os dois aviões tivessem atingido as Torres simultaneamente ou quase, a mídia não 
teria visto a colisão, apenas as consequências. Eu acredito que os Jihadistas cronometraram os sequestros para o máximo efeito espetacular, sincronizados ao ciclo de noticiários matutinos de Nova York e do meio dia na Europa. Sua intenção não era a de matar tantas pessoas quanto possível, mas alcançar um maior índice possível de audiência no Ocidente. O World Trade Center foi o epicentro não apenas dos ataques, mas também do imaginário do que é o 11 de Setembro. E que espécie de imaginário é esse?

Quando em 16 de setembro o compositor de vanguarda Karlheinz Stockhausen chamou a destruição das Torres do Worl Trade Center de a maior obra de arte imaginável para todo o cosmos, tal consideração foi recebida com ódio e aversão. Da mesma forma, ao comentar o 11 de Setembro, Dario Fo, prêmio Nobel de literatura em 1997, circulou uma mensagem de e-mail afirmando:

Os grandes especuladores chafurdam em uma economia que a cada ano mata dezenas de milhares de pessoas com a pobreza, portanto o que são 20.000 [sic] mortos em Nova York? Independentemente de quem conduziu o massacre, essa violência é a legítima herdeira da cultura da violência, da fome e da exploração humana (Apud Erlanger, 2001).

Mais tarde eu direi por que as observações de Fo não foram criticadas ao passo que Stockhausen foi ridicularizado pelas suas. Neste momento, retorno à questão da arte e as suas espécies. Isso me leva ao sublime como exposto por Immanuel Kant, em 1790. Kant escreve que a resposta ao sublime, a "[...] um prazer negativo [...] um ultraje à imaginação" é diferente da resposta positiva e afirmativa de vida ao belo (1986, p. 202). Prazer negativo e um ultraje à imaginação constituem precisamente a reação de muitos daqueles que testemunharam em tempo real ou em reprise os ataques de 11 de Setembro ao World Trade Center. Mas nós precisamos ir mais fundo na assertiva de Kant e dar uma opinião em relação à arte como nós a conhecemos e especialmente à arte de vanguarda.

Richard Schechner, 11 de Setembro, Arte de Vanguarda?

R.bras.est.pres., Porto Alegre, v.1, n.2, p. 404-425, jul./dez., 2011.

Disponível em http://www.seer.ufrgs.br/presenca 
Kant discute o sublime no registro das ocorrências naturais extraordinárias, nas quais "[...] o caos, ou a desordem e desolação mais irregulares e selvagens [dão] sinais de magnitude e poder, [ocorrências] que excitam as ideias do sublime" (1986, p. 203). Mas Kant não está satisfeito. Ele observa que se algo é

[...] grandioso e sem qualificação, absolutamente, e em todos os aspectos (para além de todas as comparações), isso quer dizer, sublime, logo se percebe que para isso não é permitido procurar um critério apropriado fora dele mesmo, mas somente nele mesmo. É uma grandiosidade comparável a ela mesma apenas. Daí vem que o sublime não deve ser procurado nas coisas da natureza, mas apenas nas suas próprias ideias (Kant, 1986, p. 207).

Em outras palavras, na medida em que o ataque do 11 de Setembro foi um ataque bem sucedido contra a imaginação, ele foi sublime.

Mas não seria obsceno considerar tal acontecimento sublime? Poderia o horrível, mesmo enquanto acontece, ser experienciado como arte? Mesmo antes de Kant, em 1757, Edmund Burkeabordou discorreu essa questão em seu tratado On the Sublime and Beautiful. A observação saliente, se perturbadora, de Burke é que até a arte imitativa executada com mais requinte não é capaz de competir com o deleite em ver as coisas que nós não iríamos de forma alguma endossar ou querer que fossem feitas. Nesse sentido, Vernon Hyde Minor observa:

[Nós] somos atraídos por catástrofes não por causa de um prazer perverso com a dor dos outros, mas porque não podemos ter uma disposição afetuosa a menos que encontremos algo agradável no espanto, algo satisfatório no horrível [...] nós somos naturalmente estetizados - ao invés de anestesiados - por terríveis acontecimentos de grande importância histórica [...]. As vastas, poderosas e terríveis forças desencadeadas pela tecnologia humana mal utilizada domina por completo as nossas faculdades cognitivas, revelando-nos a nossa própria inabilidade de compreender, ou é isso e é particularmente desafiador para um artista realizar qualquer coisa dessa magnitude (2003).

Richard Schechner, 11 de Setembro, Arte de Vanguarda?

R.bras.est.pres., Porto Alegre, v.1, n.2, p. 404-425, jul./dez., 2011.

Disponível em http://www.seer.ufrgs.br/presenca 
Estetizados - ao invés de anestesiados - por terríveis acontecimentos de grande importância histórica, isso é uma visão profunda do processo que (muitas) pessoas sofrem ao assimilar eventos que, de outra forma, seriam muito difíceis. A estetização não é a única resposta a esses tipos de eventos horríveis, mas fascinantes e atraentes, mas uma estratégia. Criar obras de arte sobre eles em protesto, admiração e, às vezes, apoio é outra resposta. E, é claro, a ação política e militar é outra ainda. Longe de querer eliminar uma resposta a favor de outra, eu prefiro mantê-las todas na consciência a respeito do ataque de 11 de Setembro ao World Trade Center.

Mas mesmo que o ataque de 11 de Setembro seja arte, ela é boa ou má do ponto de vista ético-moralpolítico? A maior parte do que chamamos arte hoje em dia carrega uma mensagem ideológica ou religiosa. No Ocidente, antes do Renascimento e do advento do capitalismo, não havia categoria de arte como tal. Noções de arte pela arte não eram teorizadas no Ocidente até os séculos XVII e XVIII. Atualmente, a maior parte da arte permanece ligada a forças fora de si mesma e não é independente ou desinteressada. A maior parte da arte é boa ou má de um modo ético-moral-político em termos de valores, operando para além ou apesar do trabalho em si. Para citar dois exemplos bem conhecidos de grandes obras de arte ruim ou maligna de acordo com o sistema de valores atual: Birth of a Nation de D. W. Griffith e $O$ Triunfo da Vontade de Leni Riefenstahl. O que é tanto óbvio quanto problemático é que determinar o que é bom e o que é ruim depende das crenças daquele que julga. Em outras palavras, pode haver algum acordo universal sobre o que é arte e o que não é arte, mas não há tal acordo, e eu nem mesmo consigo prever um tempo em que haverá um, sobre o que é ética, moral e politicamente bom ou ruim.

Pelos padrões americanos mais comuns, o ataque de 11 de Setembro foi algo maligno. Assim, é compreensível que as observações de Stockhausen

Richard Schechner, 11 de Setembro, Arte de Vanguarda?

R.bras.est.pres., Porto Alegre, v.1, n.2, p. 404-425, jul./dez., 2011.

Disponível em http://www.seer.ufrgs.br/presenca 
tenham sido recebidas com indignação. Mas por que a opinião ainda mais dura de Fo a respeito dos Estados Unidos e das vítimas do 11 de Setembro não causaram grandes distúrbios? Po que Fo não estava falando sobre arte. Ele situou o 11 de Setembro na esfera da política, da ideologia e da guerra. Stockhausen considera o 11 de Setembro como pertencente ao mundo da arte. E arte não é tão séria quanto a política; arte é jogo, secundária, uma representação. Entretanto, do ponto de vista dos Estudos da Performance, o ataque ao World Trade Center foi uma performance: planejada, ensaiada, encenada e destinada tanto a ferir materialmente os Estados Unidos quanto afetar e infectar o imaginário. A destruição de dois edifícios icônicos e o assassinato de tantas pessoas de um golpe só, tinha a intenção de enviar uma mensagem muito específica sobre a ousadia do Jihad e da vulnerabilidade dos Estados Unidos.

Uma performance, sem dúvida, mas arte? Eu acredito que o ataque possa ser entendido como a realização de ideias e impulsos chaves, impulsionando o avant-garde. Thierry de Duve escreve:

É como se a história das vanguardas fosse história dialética libertada pelas contradições da arte e da não-arte, a história de uma proibição e de sua transgressão. Um slogan poderia resumi-lo: é proibido fazer algo, vamos fazê-lo [...]. Isso é um dever e não um direito [...]. O quê poderia alguém fazer uma vez que é obrigatório que tudo seja permitido ou, como os estudantes rebeldes de Maio de 68, uma vez que é proibido proibir? (1996, p. 332-33, 340)

Visto dessa forma, o 11 de Setembro foi uma sucessão direta de manifestos e ações futuristas, anarquistas e outros manifestos e ações das vanguardas; destrutivo como os Acionistas de Viena; maciços como os edifícios e paisagens embrulhadas de Christo e JeanneClaude ${ }^{4}$. Para aqueles que se opõem à Al-Qaeda, o 11 de Setembro foi uma arte ruim do ponto de vista ético e moral. Foi arte ilegal porque os alvos eram civis. Mas foi arte de vanguarda do ponto de vista da tradição que eu estou discutindo. Seria esse tipo de análise perversa, não

Richard Schechner, 11 de Setembro, Arte de Vanguarda?

R.bras.est.pres., Porto Alegre, v.1, n.2, p. 404-425, jul./dez., 2011.

Disponível em http://www.seer.ufrgs.br/presenca 
apenas desonrando os mortos e feridos, mas também maculando o que a arte é ou deveria ser? Será que tal designação concede aos Jihadistas muito mais do que eles merecem? E isso nos ajuda a entender melhor o mundo em que vivemos?

Stockhausen (Documentação, 2009) na verdade tinha inveja dos Jihadistas. "Eu não poderia fazer aquilo. Por comparação, nós compositores não somos nada". Ele desejava o lugar mais extremo para a arte. "Artistas também às vezes tentam ir para além dos limites do que é viável e concebível, para que nos acordemos, para que nós nos abramos para outro mundo" (Documentação, 2009). Ele estava reivindicando uma importância para a arte no mundo real. Não a arte com cara de arte pendurada em museus ou ouvida em salas de concertos e teatros, mas a arte realista que Allan Kaprow realizou e teorizou: arte que é ação, não representação. De Duve escreveu antes do 11 de Setembro, enquanto Frank Lentricchia e Jody McAuliffe escreveram depois, localizando a opinião de Stockhausen entre uma longa tradição de fanáticos artísticos:

O desejo por trás de muitas visões literárias românticas é por um despertar apavorante que desfaria a ordem econômica e cultural ocidental [...]. Como qualquer artista de vanguarda o faria, Stockhausen vê a devoção da alta seriedade artística no total compromisso dos terroristas [...]. Como os terroristas, artistas sérios são sempre fanáticos; mas ao contrário dos terroristas, artistas sérios ainda não alcançaram o nível "mais alto" d[e sua] arte (Lentricchia; McAuliffe, 2003, p. 100).

Um único ataque mudou a história do mundo. Que (outro) ato artístico realizou o mesmo? Ao acabar de escrever isso, eu confesso que eu me sinto muito desconfortável. Eu argumentei a favor de uma posição que rejeito do ponto de vista ético.

Talvez a minha saída seja afirmar que a arte precisa de artistas que optam conscientemente pelo fazer artístico e espectadores que voluntariamente observam a arte. Isso sem dúvida é a tradição humanista. Mas há

Richard Schechner, 11 de Setembro, Arte de Vanguarda?

R.bras.est.pres., Porto Alegre, v.1, n.2, p. 404-425, jul./dez., 2011.

Disponível em http://www.seer.ufrgs.br/presenca 
performances rituais que são extremamente poderosas, performaticamente e artisticamente, em termos de estrutura, cor, ritmos, narrativas e assim por diante e que requerem e reforçam a participação e o testemunho. De fato, muitas obras de arte não são produto do livre arbítrio. Seriam apenas os planejadores e senhores os artistas e não os trabalhadores ou vítimas? Vamos considerar as pirâmides do Egito e de Teotihuacan, México, geralmente consideradas obras primas da arquitetura. As pirâmides egípcias foram construídas por escravos e as pirâmides de Teotihuacan e o local cerimonial ao seu redor mostram que lá aconteciam sacrifícios humanos. O tempo limpa o sangue das pedras; as pedras magníficas permanecem imaculadas pelo que antes eram experiências imediatas. $\mathrm{O}$ ataque de 11 de Setembro é muito recente, muito embebido no sangue do nosso povo, muito parte de eventos históricos não resolvidos. Nós rejeitamos a possibilidade de que o 11 de Setembro possa ser arte porque muitos membros do nosso povo foram mortos e feridos; e porque nossa psique nacional e culturas foram violadas. Da nossa perspectiva humanista o ataque foi eticamente terrível: pessoas inocentes morreram - a expressão está em destaque, pois os Jihadistas que morreram não eram inocentes. A sua presença nos aviões e nas Torres Gêmeas os marcaram como participantes na odiada cultura ocidental. Nesse modo de pensar não há neutros ou espectadores.

Ainda assim, nem Mohammed Atta nem os outros sequestradores se viam como artistas. Eles teriam rejeitado totalmente o rótulo de arte em relação às suas ações. E muitos daqueles que escrevem sobre o 11 de Setembro não o colocam no domínio da arte. Se há arte no 11 de Setembro, ela está na sua recepção e consequências: o que Stockhausen imaginou quando viu as representações do ataque feitas pela mídia. No desdobramento do evento, artistas visuais, artistas da performance, escritores, artistas de qualquer tipo podem fazer praticamente qualquer coisa com aquilo que aconteceu. Não há nada novo nisso: Goya e Picasso, sem mencionar Homero, Ésquilo, Vyasa, Shakespeare,

Richard Schechner, 11 de Setembro, Arte de Vanguarda?

R.bras.est.pres., Porto Alegre, v.1, n.2, p. 404-425, jul./dez., 2011.

Disponível em http://www.seer.ufrgs.br/presenca 
Tolstoi, Hemingway e muitos outros, realizaram obras primas com os horrores da guerra. Mas todas essas obras são reflexivas. Eles vieram depois desses crus e nao mediados eventos. O que torna o 11 de Setembro diferente é o fato de que este foi mediado desde seu início e destinado justamente a ser assim. O objetivo de seus autores não era conquistar ou ocupar um território ou mesmo dizimar tanto civis quanto possível, mas encenar um evento midiático grandioso, um show da vida real um terrível e sublime acontecimento. Como tal, isso existe tanto no domínio da propaganda quanto da estética - e existia enquanto estava acontecendo. Sua atualidade é fundamental. Ele não anula as representações após o fato: documentários, dramas, filmes, textos, relatos de primeira mão e todos os testemunhos que vieram mais tarde, como os do dia 12 de setembro e depois. Eles eram um complemento para o ataque em si, o qual já era um evento midiático, visto que já estava ocorrendo.

O liminal para esse evento foram as centenas senão milhares de cartazes e fotografias com a pergunta Voce viu?, postadas em torno e, não raro, longe do grau zero ou colocadas na internet. Esses não eram relatos do que aconteceu, nem mesmo eram parte subsequente do ataque. Eles eram uma espécie de teatro colateral (paralelo ao dano colateral de uma operação militar). Mesmo enquanto as Torres Gêmeas ainda se encontravam em chamas, pessoas já buscavam informações sobre seus entes queridos desaparecidos. A mídia se demorou nessas notícias, as quais individualmente eram apenas peças de papel, mas que coletivamente constituíam muros de ansiedade e tristeza. Cada anúncio trazia a sua esperança contra a desesperança. Ninguém sabe ao certo quantas pessoas acharam os seus por meio disso. Não tardou para que a esses anúncios se juntassem flores, um claro símbolo de condolência. Se as bolas de fogo e a impressionante onda de poeira e detritos resultantes do colapso das torres foram terríveis, magníficos e sublimes, os muros com os cartazes procurando por quem estava desaparecido eram também lamentáveis átomos individuais da angústia humana. Esses anúncios fizeram

Richard Schechner, 11 de Setembro, Arte de Vanguarda?

R.bras.est.pres., Porto Alegre, v.1, n.2, p. 404-425, jul./dez., 2011.

Disponível em http://www.seer.ufrgs.br/presenca 
parte do espetáculo, sobretudo ao fornecer um acesso de escala humana à experiência do que estava acontecendo. Pessoas que não conheciam ninguém no World Trade Center olhavam para os anúncios como uma demonstração de identificação com aqueles que perderam alguém. Os muros do Você viu? se enlaçavam à enormidade da catástrofes coletivas para milhares de expressões menores de necessidades individuais.

Lentricchia e McAuliffe não cessam de situar o 11 de Setembro dentro de uma tradição de arte transgressora. Eles discutem o 11 de Setembro em relação à cultura popular como, por exemplo, logo depois dessa data o lugar dos ataques em Nova Iorque se tornou a "Grauzerolândia" (2003, p. 05-17), a Meca (ironicamente) dos turistas e um local para a mitificação nacionalista à maneira da tradição wagneriana:

Em 30 de dezembro de 2001, o prefeito [Rudolf] Giuliani abriu para o povo uma plataforma de observação sobre o golfo mítico que é o Grau Zero, um palco no qual ele pedia aos americanos e todos os demais para vir e experimentar 'todos os tipos de sentimentos de tristeza e, disto, para um tremendo sentimento de patriotismo' [...]. O objetivo da plataforma é conectar os turistas na história e no lugar que perfeitamente conjuga o terrorismo, o patriotismo e o turismo (Lentricchia; McAuliffe, 2003, p. 103).

A plataforma já não está mais lá, mas sua intenção vive na obra da Lower Manhattan Development Corporation.

Eu bem que gostaria de ter uma conclusão mais nítida das minhas ruminações. Todavia, eu não tenho. Eu não posso acomodar em meu próprio pensamento se o 11 de Setembro é em si uma questão de arte ou se pode ser melhor entendida sob a rubrica da arte. Desde a manhã do dia 11 de Setembro em diante eu tenho problematizado isso. $\mathrm{O}$ terraço de meu apartamento tem uma visão clara daquele local em Manhattan. Naquela manhã, eu estava assistindo televisão quando escutei gritos de operários que estavam construindo um prédio na Universidade de Nova Iorque no La Guardia Place. Fui para o meu

Richard Schechner, 11 de Setembro, Arte de Vanguarda?

R.bras.est.pres., Porto Alegre, v.1, n.2, p. 404-425, jul./dez., 2011.

Disponível em http://www.seer.ufrgs.br/presenca 
terraço, olhei para o sul e, cerca de um quilômetro adiante, vi a torre norte em chamas. Eu pensei que tinha sido um acidente horrível, mas me indaguei como tal acidente poderia acontecer em um dia de céu azul e claro. Momentos depois, eu vi um avião voando baixo fazer uma curva acentuada do norte para o oeste. Ai, minha nossa!, eu disse ou pensei, algo banal e completamente em choque. Então, eu vi o avião adentrando a torre sul como uma faca quente na manteiga. Nenhum som. Um filme mudo a cores. Uma grande bola alaranjada de fogo e fumaça negra. Foi assustador; sublime; horrível; belo. Depois disso, com um intervalo de aproximadamente quarenta e cinco minutos, quando minha esposa e eu fomos buscar nossa filha na escola, eu estava no meu terraço com outros vizinhos - os quais tinham ido até ali por saberem da vista privilegiada que tínhamos. Vimos quando as torres vieram abaixo etc... o que foi que eu fiz? Eu ofereci às pessoas algo para beber e comer, disse a elas onde ficava o banheiro. Do terraço, juntos, assistimos e conversamos, nos espantamos, nos horrorizamos, nos animamos, nos assustamos, nos fascinamos com tudo aquilo. Utilizamos binóculos. Vimos algumas pessoas se lançando das torres.

Quisera eu poder relatar que havia tido apenas reações corretas, quisera eu poder ter escrito que aquilo era tão horrível que me fez dali sair, não me atrevendo a olhar, ou mesmo que eu havia superado aquilo com as noções aristotélicas de temor e compaixão. No entanto, foi um pouco mais complicado do que isso. Eu já tinha visto atuações em cordas-bambas de circo. Eu já havia assistido um monte de violência na televisão. Tudo o que aconteceu foi em silêncio. Eu não podia parar tudo e tampouco me sentia responsável por aquilo. Portanto, da minha maneira testemunhei aquilo mais como um espectador do que pensando: essa coisa terrível está acontecendo comigo. Não posso falar pelos meus vizinhos, professores e pessoas decentes de maneira geral, exceto notar que nossa conversação indicava que a resposta deles nesse momento se assemelhava a minha. As pessoas circulavam direto entre o terraço e a sala de

Richard Schechner, 11 de Setembro, Arte de Vanguarda?

R.bras.est.pres., Porto Alegre, v.1, n.2, p. 404-425, jul./dez., 2011.

Disponível em http://www.seer.ufrgs.br/presenca 
televisão. Havia certamente um sentimento de simpatia e ansiedade, mas nada comparável ao terror e compaixão próprios da catarse trágica citada por Aristóteles. A reação, para mim, veio depois, quando recolhi os eventos e os lancei para dentro do teatro de minha mente. Quando novas pessoas chegaram, elas trouxeram consigo alguns rumores e informações. Pegamos o que passou por meio da análise de especialistas em mídia. Mas, o mais importante é que todos estavam conscientes de que o que assistimos desde o norte da cidade era a coisa em si. O que nós vimos e ouvimos na televisão eram explanações e racionalizações, ambas descrevendo e modelando reações, relatando eventos e instruindo os receptores de como deveríamos reagir. A cobertura e comentaristas nos deram uma visão mais ampla para entender o que nós estávamos testemunhando, aproximando-nos com as câmeras do grau zero. Visto que assisti tanto pessoalmente quanto pela televisão, eu sei que qualquer coisa que tenha sido aquilo, eu estava experimentando um espetáculo, como um filme ao vivo, uma história acontecendo na vida real etc... Sendo o acadêmico que sou, eu me referia àquilo como $A$ sociedade do espetáculo, como aparece em Guy Debord. Além do mais, eu sabia que os Jihadistas pretendiam que assim fosse: 11 de Setembro não foi nenhum ataque disfarçado, noticiado apenas por seus efeitos devastadores, feito o anthrax por meio de carta ou veneno na água; foi um espetáculo e uma demonstração. Eu e meus vizinhos estávamos entre seus espectadores esperados, tais como eram os partidários do Jihad. Falando de modo global, nós éramos uma plateia dividida.

Estou explorando essas possibilidades não para validar as ações terroristas ou insultar a memória daqueles que morreram e sofreram, mas só pontuar que o terrorismo, na escala do 11 de Setembro, trabalha mais como arte do ponto de vista mental e sentimental do que pela destruição física propriamente dita, ou, se quiserem, que a destruição se apresenta como o meio por intermédio do qual se pode criar o terror, o que também é um estado da mente. $\mathrm{O}$ ataque do 11 de Setembro é um exemplo do

Richard Schechner, 11 de Setembro, Arte de Vanguarda?

R.bras.est.pres., Porto Alegre, v.1, n.2, p. 404-425, jul./dez., 2011.

Disponível em http://www.seer.ufrgs.br/presenca 
que Burke e Kant chamaram de sublime, despertando em alguns, senão na grande maioria dos espectadores, os sentimentos de terror e compaixão do Aristóteles da Tragédia, ao menos, sob o ponto de vista ocidental. Do ponto de vista da Al-Qaeda e seus adeptos o ataque foi visto como a ira de Deus. Ao olhar dessa forma - como evento, choque, arte de vanguarda, tragédia ou vingança o 11 de Setembro performa a estranha asserção de Artaud, presente em seu ensaio Não mais obras-primas: "Nós não somos livres. E o céu pode ainda cair sobre nossas cabeças. $\mathrm{E}$ o teatro foi criado para nos ensinar isso antes de tudo" (1958a, p. 79).

\footnotetext{
Notas

${ }^{1}$ De acordo com Thierry de Duve, Olinde Rodrigues, um seguidor de Henry de Saintsimon, escreveu em 1825: "Somos nós, os artistas, que serviremos como sua linha de frente; o poder das artes é, com efeito, a mais imediata e rápida. [...] nós nos lançamos à imaginação e aos pensamentos do povo: deveríamos, portanto, alcançar a mais vivida e decisiva espécie de ação" (1996, p. 430-431).

${ }^{2}$ Para saber mais sobre a relação entre terrorismo e televisão, ver Dayan (2006).

${ }^{3}$ N.T.: Comece a espalhar a notícia, estou partindo hoje/Eu quero ser parte dela - New York, New York [...]/Se eu conseguir lá, eu conseguirei em qualquer lugar.

${ }^{4}$ Ver <www.christojeanneclaude.net>.
}

\section{Referências}

ARTAUD, Antonin. No More Masterpieces. In: ARTAUD, Antonin. Artaud Theater. New York: Grove Weidenfeld, 1958a, p.74-83.

ARTAUD, Antonin. The Theater and Cruelty. In: ARTAUD, Antonin. Artaud Theater. New York: Grove Weidenfeld, 1958b, p. 84-88.

ARTAUD, Antonin. The Theater and its Double. New York: Grove Weidenfeld, $1958 \mathrm{c}$.

BECK, Julian. The Life of the Theatre: the relation of the artist to the struggle of the people. San Francisco: City Lights, 1972.

BRETON, Andre; TROSTSKY, Leon. Towards a Free Revolutionary Art. Disponível em: <generation-online.org>. Acesso em: 22 jul. 2009.

BURKE, Edmund. A Philosophical Inquiry into the Origin of Our Ideas of the Sublime

Richard Schechner, 11 de Setembro, Arte de Vanguarda?

R.bras.est.pres., Porto Alegre, v.1, n.2, p. 404-425, jul./dez., 2011.

Disponível em http://www.seer.ufrgs.br/presenca 
and Beautiful, with several other additions. The Harvard Classics. Ed. Charles W. Eliot. v. 4, PT. 2. New Yorl: Collier, 1909-1914. Disponível em: <bartleby.com>. Acesso em: 25 jun. 2009.

DAYAN, Daniel (Org.). La Terreur Spectacle. Paris: De Boeck U, 2006.

DEBORD, Guy. The Society of the Spetacle. London: Verso, 1990.

De DUVE, Thierry. Kant after Duchamp. Cambridge: MIT Press, 1996.

STOCKHAUSEN, Karlheinz, Documentation of Stockhause's Comments re: 9/11, William Osborne and Abbie Conant, (não publicado), acessado em 24 junde 2009.

ERLANGER, Steven. A Nation Challenged: voices of opposition. New York Times, New York, 22 set. 2001.

HESSLER, Peter. Oracle Bonés. New York: Harper, 2007.

KANT, Immanuel. Critique of Judgement. In: KANT, Immanuel. Immanuel Kant Philosophical Writings. Ed. Ernst Behler. New York: Continuum, 1986. P. 129-246.

LENTRICHIA, Frank; McAULIFFE. Crimes of Art and Terror. Chicago: University of Chicago Press, 2003.

MARINETTI, Filippo Tommaso. Tee Futurist Manifesto. Cosma's Home Page. Center for the study of complex systems. University of Michigan, não disponível, acessado em 25 de junho de 2009.

MINOR, Vernon Hyde. What Kind of Tears? 9/11 and the Sublime, Journal of American Studies of Turkey. New York, v. 14, fall 2003, p. 91-96.

SINATRA, Frank. New York, New York. Trilogy: Past Present Future. Reprise Records, 1980.

Situationist Manifesto. Trans. Fabian Thompsett. Sitautionist Intl. Online, não disponível, acessado em 22 de julho de 2009.

THE OXFORD ENGLISH DICTIONARY. Avant-Garde. 1989.

TZARA, Tristan. The Second Dada Manifesto. The First and Second Dada Art Manifestos. The Art History Archive. Lilith Gallery Network, não disponível, acessado em 22 de julho de 2009.

Richard Schechner, 11 de Setembro, Arte de Vanguarda?

R.bras.est.pres., Porto Alegre, v.1, n.2, p. 404-425, jul./dez., 2011.

Disponível em http://www.seer.ufrgs.br/presenca 
Richard Schechner é doutor pela Tulane University. É fundador e professor do Departamento de Estudos da Performance da Universidade de Nova Iorque. Autor de diversos livros e artigos, incluindo Between Theather and Anthropology (Penssylvania University Press, 1985) e Performance Studies - an introduction (Routledge, 2006). Sua mais recente produção teatral foi Mandarin Hamlet (2009), encenado em Shanghai e Wroclaw.

E-mail: rs4@nyu.edu

Traduzido do original em inglês por Marcelo de Andrade Pereira e Martin Dahlström Heuser e revisado por Gilberto Icle

Recebido em Junho de 2011

Aprovado em Agosto de2011 